\title{
AZ ÖNKÉNTESSÉG MOTIVÁCIÓS ELMÉLETEI INTEGRATÍV \\ KERETBEN
}

\section{DORNER LÁSZLÓ1}

DOI: https://doi.org/10.53585/OnkSzem.2021.1.39-55

\section{Absztrakt}

Az önkéntesség végzése mögötti motivációs rendszer azonosítása régóta a tudományos kutatások fókuszában áll. Jelen tanulmányunk célja, hogy az utóbbi évtizedek ez irányú kutatásainak főbb irányait összehasonlító keretben, integratív céllal bemutassa. Továbbá megvizsgálja azt, hogy a különböző szükségletek kielégítése hogyan függ össze az önkéntesség időtartamával, intenzitásával, az önkéntesség élményeinek feldolgozásával. Eredményeink szerint az önkéntesség végzése mögött meghúzódó motivációs struktúra megértését segíti, ha változatos szemléleti keretből vizsgálódunk. Ennek érdekében a kétirányútól (altruisztikus-énorientált, explicit-implicit, öndeterminációs elmélet) a multimotivációs (funkcionális szemlélet) elméletek felé haladva elemezzük, hogy az önkéntes tevékenységek és fogadó szervezetek sokszínúségének, a velük való megelégedettségnek, a munkavégzés eltérő intenzitásának és gyakoriságának egyaránt meghatározó szerepe van a motivációs struktúra egyéni változásaiban, és az arra irányuló döntésre, hogy az egyén meddig folytatja az önkéntes tevékenységet. A kurrens kutatások alapján úgy tűnik, hogy a legtöbb önkéntes vegyes motivációs bázist mutat (altruisztikus és énorientált), továbbá, hogy explicit és implicit, valamint extrinzik és intrinzik motívumok egyaránt szerepet játszanak a proszociális elkötelezettségben. Mindezek alapján kijelenthetjük, hogy az önkéntesség motivációs háttere nagy egyéni változatosságot mutat, idővel változhat. Mérése során a felszíni struktúrák nagy mintákon történő vizsgálatára alkalmas kérdőíves módszertant érdemes a mélyebb struktúrák azonosítását is lehetővé tevő kvalitatív módszertannal kiegészítenünk.

Kulcsszavak: önkéntesség, motivációk, altruizmus, öndeterminációs elmélet, implicit-explicit

\section{Motivational theories of volunteering in an integrated framework}

\section{László Dorner}

\section{Abstract}

Identifying the motivational system behind volunteering has long been the focus of scientific research. The aim of our present study is to analyze and integrate the main directions of research in this field during recent decades in a comparative framework. The study also seeks to demonstrate how fulfilling various needs is related to the longevity, frequency, and nature of volunteering. Our study emphasizes the significance of understanding the motivational structure of volunteering from diverse perspectives.

\footnotetext{
${ }^{1}$ Dorner László (PhD) pszichológus, egytemi adjunktus, Eszterházy Károly Egyetem, Pszichológia Intézet
} 
The theories are discussed from two-dimensional (eg altruistic-ego-oriented, explicit-implicit, selfdetermination theory) to multifactorial (functional analysis) approaches, emphasizing that the diversity of volunteer activities and host organizations, the satisfaction with these associations, and the intensity and frequency of volunteer work all contribute to individual changes in motivational structure and to the decision to become a long term volunteer. Based on the current literature, we can state that most volunteers show a mixed motivational base (altruistic and ego-oriented), and that explicit and implicit as well as extrinsic and intrinsic motives play a role in prosocial engagement. We can highlight that the motivational background of volunteering shows great individual variability, and it may change over time. We may also conclude that it is worth supplementing the questionnaires suitable for the large-scale examination of surface structures with a qualitative methodology that allows the identification of deeper structures.

Keywords: volunteering, motivations, altruism, self-determination theory, implicit-explicit

\section{AZ ÖNKÉNTESSÉGGEL KAPCSOLATOS MOTIVÁCIÓS ELMÉLETEK}

Évtizedek óta az önkéntes magatartás kutatásának egyik legizgalmasabb területe a cselekedet mozgatórugóit magyarázó motivációk kutatása. A motiváció az embereket cselekvésre sarkalló, energizáló és egyúttal a viselkedés dinamikáját meghatározó, annak irányt adó tényező (Ryan - Deci 2017). Az önkéntesség kapcsán mindez azért nagyon fontos, mert már az önkéntesség megkezdése, majd folytatása, illetve esetleges abbahagyása vagy elkerülése mögött is azonosítható egyéni motivációs mintázat. Azonban joggal vethetjük fel a kérdést, hogy ezen egyéni mintázatokból összeállnak-e olyan, a nagyobb közösségre is általánosítható mintázatok, melyek ezeket a döntéseket magyarázzák. A következő fejezetekben azon elméleti megközelítéseket mutatjuk be, melyek az elmúlt évtizedekben meghatározták a téma kutatását (1. táblázat).

\section{Altruisztikus - énorientált motívumok}

Az önkéntesség motivációs hátterének vizsgálatában több, ún. kétirányú elmélet látott napvilágot. Itt olyan elméleteket találunk, ahol a személy cselekedete vagy besorolható az egyik motivációs típusba (dichotóm, például: implicit vagy explicit), vagy egy dimenzió (például: az altruisztikus - énorientált skála) valamely pontján helyezkedik el, pl. erősebb a másokra irányuló motivációja az önkéntesség kapcsán, mint a saját szükségletei kielégítésének vágya. Ezek közül az egyik legmeghatározóbb irány az altruisztikus - énorientált motiváció vizsgálata (Widjaja 2010). Az altruisztikus motívumok által dominált önkéntes számára más személyek vagy csoportok jól-létének növelése fontosabb, mint a saját szükségleteinek a kielégítése (Snyder - Omoto 2009; Widjaja 2010). 
1.táblázat A tanulmányban ismertetésre kerülő elméletek

\begin{tabular}{|c|c|c|c|}
\hline \multicolumn{3}{|c|}{ Kétirányú elméletek } & Multidimenzionális \\
\hline $\begin{array}{c}\text { Altruisztikus - } \\
\text { énorientált } \\
\text { motívumok }\end{array}$ & $\begin{array}{c}\text { Önmeghatározás elmélet } \\
\text { • intrinzik - extrinzik } \\
\text { motiváció } \\
\text { • alapvető pszichológiai } \\
\text { szükségletek } \\
\text { (autonómia, } \\
\text { kompetencia és } \\
\text { kapcsolódás) } \\
\text { • önirányítottság } \\
\text { (autonóm - kontrollált } \\
\text { motiváció) }\end{array}$ & $\begin{array}{c}\text { Explicit - implicit } \\
\text { proszociális } \\
\text { motiváció }\end{array}$ & $\begin{array}{l}\text { Funkcionális szemlélet } \\
\text { • VFI (Volunteer } \\
\text { Functions Inventory) } \\
\text { - VMI (Volunteer } \\
\text { Motivation Inventory) } \\
\text { - Magyar Önkéntes } \\
\text { Motivációs Kérdőív } \\
\text { (MÖMK) }\end{array}$ \\
\hline
\end{tabular}

Forrás: Saját szerkesztésű táblázat

Az ilyen önkéntes általában magas empátiával rendelkezik, érzékeny a társas környezetében található személyek érzelmi állapotára, hamar a segítségét ajánlja fel, ha szükségesnek látszik. Kiemelten fontosnak tartja az emberi kapcsolatok ápolását, proszociális értékrendje kifejezését, gyakran társadalmi és morális felelősségvállalása magas szintű.

Ezzel szemben az az önkéntes, akit az énorientált motívumok dominanciája határoz meg, azt tekinti a legfontosabbnak, hogy számára az önkéntesség kézzelfogható előnyökkel, jutalmakkal járjon. Ilyen lehet például a karrierhez kapcsolódó előnyök, új barátok szerzése, új készségek elsajátítása, de akár a dicséret, figyelem kivívása, a saját jól-lét érzés növelése, maga a tevékenység általi jó érzés, vagy az elismerés és önbecsülés szükségletének kielégítése (Davis et al. 2003) is. Ha a személy motivációs struktúrájában az énorientált szükségletek is megjelennek, alapvetően nem jelent problémát, hiszen általában amúgy is vegyes motivációs bázis azonosítható az önkéntesség hátterében (Dorner 2020), valamint eltérő, hogy milyen önkéntes tevékenységeket találunk jutalmazó erejűnek. Vannak olyan tevékenységek (pl. vendégek fogadása), ahol bizonyos feladatkörökben az erősebb önbemutatási igény még előnyös is lehet a munka sikeressége szempontjából. Ugyanakkor, ha a személy szélsőségesen énorientált, gátolhatja is a hatékony munkavégzést (pl. nem jelenik meg, ha hamar kell felkelni, vagy sokat kellene utazni). Ilyenkor gyakran alacsonyabb másokra irányultsággal találkozunk, ami pedig az önkéntesség fontos feltétele. Az ilyen személyek a közönség jelenlétében többet önkénteskednek, mivel a társas megítélésük javításának lehetőségét 
látják a proszociális cselekedetekben. Jobban élvezik azt is, amikor a hős vagy megmentő szerepében tüntethetik fel magukat (Konrath et al. 2016).

A kutatások összefüggést találtak az önkéntesség intenzitása, időtartama és a motivációs háttér között. A hosszú távon aktív önkénteseknél szignifikánsan gyakrabban találunk altruisztikus motivációs hátteret, mint az epizodikus (alkalmi) önkénteseknél, akik viszont több énorientált motívum, például az önéletrajz csinosítása érdekében végzik azt (Handy et al. 2006). A fenti összefüggést az is magyarázhatja, hogy azon önkéntesek, akik erősebb vágyat éreznek humanitárius vagy altruista értékrendjük kifejezésére, az önkéntesség által ezt könnyen megtehetik. Jóval több időt is töltenek vele, mint akik kevésbé altruisták, mivel énjük könnyebben kifejezésre kerülhet ezen tevékenységek végzése közben, különösen, ha erős szervezeti vagy személyi kötődésük van afelé, ami/aki számára az önkéntességet végzik (Shantz et al. 2014).

Érdekes egészséglélektani összefüggés, hogy míg az altruizmus motivált önkéntesek között számottevően alacsonyabb mortalitási rátát mutattak ki a kutatók egy 4 éves utánkövetéses vizsgálatban a nem önkéntesekhez viszonyítva, ugyanez az énorientált önkéntes motivációjú személyekre nem igaz (Konrath et al. 2012).

\section{Öndeterminációs elmélet}

A másik nagy hatású megközelítés, amiről szót ejtünk, az úgynevezett öndeterminációs elmélet (self-determination theory) nevet viseli, amely a hazai szakirodalomban néhol önmeghatározás elméletként is szerepel, így néha ezt a terminust is használni fogjuk. Az elmélet hamar népszerúvé vált az önkéntesség kutatói körében.

Az elmélet szerint az emberek természetes hajlammal rendelkeznek a személyes növekedésre, az önfejlesztésre és a belső egyensúly megteremtésére. Ugyanakkor aktívan keresik a kihívásokat, törekednek tudásuk bővítésére és új készségek elsajátítására (Deci - Ryan 2008). Mivel folytonos interakcióban állnak környezetükkel, ez ösztönözheti, gátolhatja vagy meg is akadályozhatja az emberi természet ezen pozitív aspektusának kiteljesedését. $A z$ öndeterminációs elméletet ma hat minielméletből álló metateóriaként tartjuk számon, melyek közül az önkéntesség szempontjából legfontosabb elméleti alapvetések bemutatására szorítkozunk áttekintésünkben. 


\section{Intrinzik-extrinzik motiváció}

Az öndeterminációs elmélet szerint a motivációnak egyaránt van minőségi és mennyiségi aspektusa (Deci - Ryan 1985). Előbbi kapcsán alapvetően intrinzik és extrinzik motivációs tényezőket különít el (Deci - Ryan 2000; Ryan - Deci 2000a).

Az intrinzik motivált önkéntességről Deci és Ryan (1985) szerint akkor beszélünk, ha a személy saját elhatározásából végzi, a cél maga a tevékenység fenntartása, a tanulás, a fejlődés vágya vagy a kíváncsiság. Ilyenkor a személy a tevékenységet magát érdekesnek találja és annak végzése önjutalmazó jellegű számára, tehát mindenféle külső motiváció nélkül is folytatná. Amabile (1993) szerint az intrinzik motiváció tartósabb munkavégzéssel és magasabb önkéntességgel töltött idővel jár együtt.

Az extrinzik motivált önkéntes viszont alapvetően külső tényezők (másoknak való megfelelés, anyagi elismerés, társas nyomás) hatására végzi a cselekvést.

Finkelstein (2009) eredményei alapján elmondhatjuk, hogy az intrinzik motivált önkéntesekre nagyobb valószínúséggel jellemző a proszociális személyiség, míg az extrinzik motivált önkéntesek számára a tevékenység élvezete helyett a külső célok (szakmai előmenetel, szorosabb társas kapcsolatok) elérése a legfontosabb az önkéntes tevékenység végzésekor.

\section{Pszichológiai Alapszükségletek Elmélete}

A Pszichológiai Alapszükségletek Elmélete szerint elsősorban azok a viselkedések, élmények járulnak hozzá az egészséges múködéshez (integritás, növekedés, pszichológiai jól-lét), amelyek biztosítják a személy számára a pszichológiai alapszükségletek kiegyenlített és magas szintű kielégülésének érzését.

Az első alapszükséglet az autonómia, ami a saját szándék és belső szabadság felismerése és alkalmazása, mellyel a személyes értékei és identitása alapján tud dönteni valamely cselekvés végrehajtása mellett.

Második alapszükségletünk az affiliáció (kapcsolódás) szükséglete: az emberek társas csoportokba szeretnek tartozni, más személyekhez kapcsolódni, szeretni és szeretve lenni, törődést adni és kapni.

Utolsó alapszükségletünk a kompetencia, vagyis kapcsolatba kerülve másokkal szeretnék hatékonynak is érezni magukat. Annak megtapasztalását jelenti, hogy képesek vagyunk különböző cselekedeteket sikeresen végrehajtani. 
Ezen szükségletek kielégítettsége a pszichés jól-léttel is komoly kapcsolatot mutat. Szisztematikus vizsgálat-sorozatukban Weinstein és Ryan (2010) két héten át követték vizsgálati személyeik segítő viselkedéseinek hatását a személyre és a segítés haszonélvezőjére nézve. Eredményeik szerint azokon a napokon, amikor a személyek saját akaratból, autonóm motiváltan végezték a segítő tevékenységet, a munkavégzést követően magasabb jól-lét, vitalitás és önértékelés volt kimutatható náluk, valamint több pozitív érzésről, és a kliensekkel való közelségérzés fokozódásáról számoltak be. A vizsgálat azt is kimutatta, hogy a segítő tevékenység során megtapasztalt kapcsolódás iránti igény, valamint az autonómiaszükséglet kielégítése a jóllét-mutatók eróteljesebb prediktorainak bizonyulnak, mint a segítés során megélt kompetenciaélmény. Továbbá, hogy a segítés haszonélvezői (a recipiensek) magasabb jóllétről, az önkéntesekkel való fokozott közelségérzésről számoltak be a segítést követően akkor, ha autonóm motivált személyek dolgoztak velük.

\section{Az önirányítottság (autonóm-kontrollált szabályozás)}

A magatartás önszabályozottsága történhet autonóm vagy kontrollált módon. A kontrolláltan szabályozott viselkedések azok, melyek externális (külső) vagy belsővé vált motivációk hatására jönnek létre. Az autonóm módon szabályozott magatartásról pedig akkor beszélhetünk, amikor olyan tevékenységeket végzünk, amelyek számunkra fontosak, értékesek (azonosulás és integráció), illetve belső jutalom, élvezet és öröm fúződik hozzájuk (intrinzik motiváció) (Martos 2016). Ahogy a 2. táblázatban láthatjuk, ezek egy motivációs kontinuumot alkotnak az amotivált viselkedéstől a teljes belső motiváltságig (öndetermináció) az okság észlelt helye és a szabályozási folyamatok alapján (Ryan - Deci 2000a).

Az amotiváció azt jelenti, hogy a személy nem mutat semmilyen szándékot, motivációt a cselekvés végrehajtására, tehát az adott viselkedéssel kapcsolatban az önirányítottság teljes hiányát mutatja (Martos 2016). Ennek oka lehet, hogy a személy nem bízik abban, hogy általában az emberek kontrollt tudnak gyakorolni az események kimenetele fölött, vagy a saját, a tevékenység végrehajtásához szükséges képességeiben nem hisz (Ryan - Deci 2017). Az extrinzik motivált viselkedések a szabályozás mértéke alapján kontinuumot alkotnak: négy típusát különböztetik meg a téma kutatói, ezekből kettő eleve önmeghatározott típusú, kettő pedig kevésbé az.

A külső szabályozás olyan extrinzik motivált, nem önszabályozott viselkedést ír le, amely függ a külső szabályzóktól, vagyis amelyet külső jutalmak elérése vagy a büntetés elkerülése 
motivál (pl. az a fiatal, aki azért önkénteskedik, hogy iskolai követelményeket teljesítsen általa, vagy mások tetszését elnyerje). Ilyenkor az önkéntesség iránti elköteleződés oka a személyen kívül keresendő.

Az introjektált szabályozás szintén nem önmeghatározott viselkedésekre utal. Ilyenkor azért végzi a tevékenységet, hogy elkerülje a búntudatot, szégyenérzetet, hogy mások elismerését elnyerje (pl. azért cselekszik, hogy megszabaduljon az amiatti búntudatától, hogy szerencsésebb, mint mások).

2. táblázat Az öndeterminációs elmélet föbb aspektusai

\begin{tabular}{|c|c|c|c|c|c|c|}
\hline $\begin{array}{c}\text { Motiváció } \\
\text { típusa }\end{array}$ & Amotiváció & \multicolumn{4}{|c|}{ Extrinzik motiváció } & $\begin{array}{l}\text { Intrinzik } \\
\text { motiváció }\end{array}$ \\
\hline $\begin{array}{c}\text { A } \\
\text { viselkedés- } \\
\text { szabályozás } \\
\text { típusa }\end{array}$ & $\begin{array}{c}\text { Nincs } \\
\text { szabályozás }\end{array}$ & $\begin{array}{c}\text { Külső } \\
\text { szabályozás }\end{array}$ & $\begin{array}{l}\text { Introjektált } \\
\text { szabályozás }\end{array}$ & $\begin{array}{l}\text { Identifikált } \\
\text { szabályozás }\end{array}$ & $\begin{array}{c}\text { Integrált } \\
\text { szabályozás }\end{array}$ & $\begin{array}{c}\text { Intrinzik } \\
\text { szabályozás }\end{array}$ \\
\hline $\begin{array}{c}\text { A cselekvés } \\
\text { oka }\end{array}$ & $\begin{array}{l}\text { Nincs szándék a } \\
\text { cselekvésre, } \\
\text { nem érzi magát } \\
\text { kompetensnek }\end{array}$ & $\begin{array}{l}\text { Külső jutalmak } \\
\text { szerzése vagy } \\
\text { a büntetés } \\
\text { elkerülése }\end{array}$ & $\begin{array}{c}\text { Mások } \\
\text { helyeslésének } \\
\text { megszerzése vagy } \\
\text { bűntudat } \\
\text { elkerülése }\end{array}$ & $\begin{array}{l}\text { A cselekvés } \\
\text { fontos és } \\
\text { értékes a } \\
\text { személy } \\
\text { számára }\end{array}$ & $\begin{array}{l}\text { A cselekvés } \\
\text { konzisztens a } \\
\text { célokkal, a } \\
\text { szelffel és az } \\
\text { értékrenddel }\end{array}$ & $\begin{array}{l}\text { Élvezetes és } \\
\text { kielégítő a } \\
\text { cselekvés } \\
\text { Érdeklődés }\end{array}$ \\
\hline $\begin{array}{c}\text { Az okság } \\
\text { észlelt helye }\end{array}$ & Személytelen & Külső & $\begin{array}{l}\text { Valamennyire } \\
\text { külső }\end{array}$ & $\begin{array}{c}\text { Valamennyire } \\
\text { belső }\end{array}$ & Belső & Belső \\
\hline $\begin{array}{l}\text { Példák az } \\
\text { állításokra }\end{array}$ & $\begin{array}{l}\text { „Nem igazán } \\
\text { gondolkodom } \\
\text { önkéntességen” }\end{array}$ & $\begin{array}{l}\text { „Az önk. általi } \\
\text { elismerés } \\
\text { motivál” }\end{array}$ & $\begin{array}{l}\text { „Büntudatom } \\
\text { lenne, ha nem } \\
\text { önkénteskednék” }\end{array}$ & $\begin{array}{l}\text { „Az önk. } \\
\text { fontos } \\
\text { számomra” }\end{array}$ & $\begin{array}{c}\text { „Az } \\
\text { önkéntesség az } \\
\text { életem } \\
\text { integráns része } \\
\text { lett” }\end{array}$ & $\begin{array}{c}\text { „Élvezem az } \\
\text { önkéntességet } \\
\text { és érdekel” }\end{array}$ \\
\hline
\end{tabular}

Forrás: Saját szerkesztésű táblázat Bidee et al 2013 alapján.

Az ún. azonosuláson alapuló (identifikált) szabályozás esetén a tevékenység majdnem teljesen a szelfbe integrált, ezáltal a szabad választás érzését adja (például, amikor az önkéntességet egy személyesen fontos ügyért való munkálkodásnak éli meg a személy; Deci - Ryan 2000). Ez már részben autonóm cselekvés, de még mindig extrinzik motivált.

Az ún. integráción alapuló szabályozás olyan extrinzik motivált viselkedéseket takar, amelyeket a személy teljesen énazonosnak ítél meg, és más identifikációkkal, értékekkel és szükségletekkel is asszimilálta már a személy (pl. amikor önkéntesnek lenni központi részét képezi valaki identitásának). Észrevehetjük tehát, hogy az identifikált és az integrált viselkedés egyrészt extrinzik, egyszersmind pedig autonóm motivációosztályba is beletartozik. Ennek oka, hogy az extrinzik motivált viselkedések azáltal válnak autonóm motiválttá, hogy a személy 
azonosul a tevékenységgel és értékesnek látja a kívülről jövő viselkedést, vagy még inkább, ha más értékeivel vagy hiedelmeivel integrálódik, tehát minél internalizáltabb, annál autonómabb a cselekvés. Ilyenkor már lényegesen nagyobb viselkedési szándékot, kitartást és teljesítményt azonosíthatunk (Dorner, 2020).

\section{Explicit és implicit proszociális motiváció}

A 2010 előtti, főleg önbevalláson alapuló kérdőíves vizsgálatok elsősorban az önkéntesség végzése mögött meghúzódó tudatos, explicit motívumok feltárását célozták meg. A nem tudatos (implicit) aspektusok szerepére először Aydinli et al. (2014) hívták fel a figyelmet, akik az explicit és az implicit motívumok interakcióját feltételezték a hosszú távú önkéntesség hátterében.

Az implicit proszociális motiváció kora-gyermekkorban alakul ki, még a nyelvelsajátítás előtti tapasztalatok hatására (McClelland - Pilon 1983), és tudatosan nem jelenik meg, az egyén kontrollján kívül esik. Azaz, tudattalanul irányítja az egyént az érzelmileg jutalmazó végállapotok felé (Schultheiss 2008). Az implicit motívum jól jelzi előre a spontán segítségnyújtásra irányuló szándékot és az olyan hosszú távú viselkedéseket, melyekben a személy intuitíven köteleződik el. Az implicit proszociális motiváció kialakulásában szerepet játszhat még az idősebb testvér léte (Aydinli et al. 2015), és összefügghet a szülővé válás esélyével (Chasiotis et al. 2006) is.

Az explicit motívumok ezzel szemben a nyelvelsajátítást és fogalomalkotást követő, szocializációs tapasztalatok során elsajátításra kerülő motívumokat takarják. Tudatosan, a személy kontrollja alatt, a kogníciónk által irányítottan múködnek, így az explicit motívumok szociálisan elfogadott viselkedéses kimenetelek felé haladnak, melyeket az egyén kívánatosnak tart, a saját döntése, hogy követni fogja ezeket a célokat a kívánt végkimenetel elérése érdekében (McClelland et al. 1989). Az explicit proszociális motiváció erős összefüggést mutat a hosszú távú önkéntességgel és általában a tervezett cselekvésekkel. Ez a kapcsolat akkor a legerősebb, amikor az implicit (tudattalan) proszociális motiváció szintén magas szintű, vagyis amikor motivációs rendszere kongruens (Aydinli et al 2014, 2015, 2016). Az önkéntesség tehát, mint tervezett, tudatos végiggondolást és jól strukturált szituációkat, de néhol intuitív döntéshozatalt is igénylő cselekvés, és mind az explicit, mind pedig az implicit motívumokkal kapcsolatot mutat (Perugini et al 2011). 


\section{MULTIDIMENZIONÁLIS ELMÉLETEK}

A kétirányú elméletek nem tudják teljes mértékben megmagyarázni az önkéntesség hátterében megjelenő motivációs változatosságot, így mindenképpen szót kell ejtenünk a multidimenzionális elméletekről.

\section{Funkcionális szemlélet}

A multidimenzionális elméletek közül a legismertebb az úgynevezett funkcionális szemlélet, amely szerint az emberek többsége azért végez önkéntes tevékenységeket, hogy egy vagy több szükségletét kielégítse általa. Ugyanaz az önkéntes munka eltérő szerepet tölthet be a különböző egyéneknél, több motívumot szolgálhat egy időben és az egyes személyek önkéntességre irányuló motivációi változhatnak is idővel (Finkelstein 2009).

Az elmélet azt feltételezi, hogy az egyének azért kezdik el, majd addig folytatják az önkéntességet, amíg a tevékenység illeszkedik motivációs késztetéseikhez, illetve amíg kielégíti azokat (Clary - Snyder 1999). Ezen elmélet alapján került kidolgozásra az önkéntes motiváció mérésére legrégebben alkalmazott eszköz, a Clary et al. (1998) által kidolgozott Önkéntes Funkciók Leltára (Volunteer Functions Inventory, VFI), mely az önkéntesség végzése mögött 6 féle motívumot (viselkedésre késztető belső tényezőt) jelenít meg, amelyek a 3 . táblázatban kerülnek részletes kifejtésre. A 6 motívum közül egyedül az érték dimenzió tekinthető altruisztikusnak, a többi 5 pedig énorientált motívum (Güntert et al. 2016).

A fentebb ismertetett VFI a legszélesebb körben elfogadott, leggyakrabban használt (Rokach - Wanklyn 2009), és nemzetközi mintán legmagasabb reliabilitás mutatókkal rendelkező mérőeszköz. Chacón et al. (2017) összehasonlították a legfontosabb, VFI-vel önbevallásos alapon végzett kutatások eredményeit. Eredményeik szerint az értékmotiváció a legmeghatározóbb az önkénteseknél, ezt követi a megértés, valamint arra is rámutattak, hogy a 40 éven aluliaknál sokkal inkább jellemző a karrier motiváció, mint 40 év fölöttieknél. $\mathrm{Az}$ érték motiváció az a személyes értékrend kifejezése mellett a mások iránti humanitárius elkötelezettséget, valamint a közösségével való törődést is jelentheti (Snyder - Omoto 2009). Ugyanakkor az utóbbi évtizedben több, főként kvalitatív módszertannal végzett kutatás szerint a VFI faktorstruktúrája nem képezi le teljes mértékben az önkéntesség mögött meghúzódó motivációs változatosságot. Allison és mtsai (2002) 195 önkéntessel készített, nyitott végű kérdéseket felhasználó vizsgálatukban arra jutottak, hogy három további motivációs faktort 
mutathatunk ki az önkéntesség iránti elköteleződés hátterében: a vallásosságot, az élvezeti értéket és csapatépítést, míg Hochstetler (2014) szerint a közösség iránti elkötelezettséggel és a viszonzás vágyával kellene kiegészíteni a fenti motivációs listát.

\section{3. táblázat Az önkéntesség hatfaktoros modellje, VFI}

\begin{tabular}{|c|c|}
\hline $\begin{array}{l}\text { 1. érték dimenzió: azért végez önkéntes } \\
\text { tevékenységet, hogy fontos értékeket } \\
\text { fejezzen ki vagy müködtessen, például } \\
\text { az emberiesség vagy a kevésbé } \\
\text { szerencsés helyzetben levők segítése }\end{array}$ & $\begin{array}{l}\text { 2. megértés szükséglete: az a szándéka, } \\
\text { hogy többet tudjon meg az őt körülvevő } \\
\text { világról és kevéssé használt képességeit } \\
\text { fejlessze, tapasztalatokat szerezzen; }\end{array}$ \\
\hline $\begin{array}{l}\text { 3. növekedés szükséglete: célja, hogy a } \\
\text { személy pszichológiai értelemben } \\
\text { fejlődjön az önkéntes tevékenység } \\
\text { közben átélt pozitív érzések hatására, } \\
\text { miközben önbecsülése növekedését és a } \\
\text { személyes fejlődés érzését is } \\
\text { megtapasztalhatja. }\end{array}$ & $\begin{array}{l}\text { 4. karrierszükséglet: célja a pályájával } \\
\text { összefüggő tapasztalat növelése és jobb } \\
\text { karrier lehetőségek szerzése az } \\
\text { önkéntesség által (pl. önéletrajz } \\
\text { bővítése); }\end{array}$ \\
\hline $\begin{array}{l}\text { 5. tórsas szükséglet: az önkéntesség által a } \\
\text { személy szélesíteni szeretné társas } \\
\text { kapcsolatait, vagy számára fontos } \\
\text { személyek elismerését szerezheti meg } \\
\text { általa; }\end{array}$ & $\begin{array}{l}\text { 6. énvédelem szükséglete: azért } \\
\text { önkénteskedik, hogy csökkentse negatív } \\
\text { érzéseit, bűntudatát, elmeneküljön az } \\
\text { aktuális helyzetből, vagy személyes } \\
\text { problémáit megossza másokkal. }\end{array}$ \\
\hline
\end{tabular}

Forrás: Clary et al 1998 alapján Dorner 2020.

Egyetértve ezzel, Vecina és Marzana (2019) nyitott végű kérdések tartalomelemzése alapján hozzáteszi még a tevékenység élvezetét, a társadalmi igazságosság előmozdítását, a személyes növekedést és a feladat iránti érdeklődést, mint számottevő motivációs faktorokat. Fox és mtsai (2010) kvalitatív adatelemzése az érték motiváció dominanciája mellett kiemeli a társas motívum jelentőségét is, ami számos célt szolgálhat az önkéntesség kapcsán: kapcsolatépítés, valahova tartozás érzése, értékes kapcsolat más önkéntesekkel és az önkéntesség haszonélvezőivel. Természetesen fontos motivációnak tekinthető a vallásosság is az önkéntesség végzésekor, számos kutatás említi, főként a szolgálatként felfogott, értékalapú segítségnyújtás szerepét kiemelve (Gibson 2008).

Hazai mintán - szintén multifaktoriális elméleti alapokon, a Volunteer Motivation Inventory, (VMI) (Esmond - Dunlop 2004) adaptációját elvégezve - először Bartal Anna Mária (2010) vizsgálta az önkéntesek motivációit, szociológiai nézőpontból. A Magyar Önkéntes Motivációs Kérdőív (Bartal - Kmetty 2011) 59 állítást tartalmazott, a faktoranalízis eredményeképpen az alábbi 15 önkéntes motivációs faktor jött létre: (1) érték faktor, (2) megértés faktor, (3) 
társadalmi faktor, (4) önvédelem (protektivitás) faktor, (5) karrierfejlesztés faktor, (6) elismertség faktor, (7) szociális interakciók faktor, (8) reciprocitás faktor, (9) visszahatás (reaktivitás) faktor, (10) önmegbecsülés faktor, (11) vallás faktor, (12) helyi önkormányzati hiányok faktor, (13) kormányzati hiányok faktor, (14) kultúra faktor és (15) környezet faktor.

Mint láthatjuk, a hatfaktoros modellnél lényegesen komplexebb struktúrát vázoltak a szerzők. Ennek hátterében az állt, hogy a hazai önkéntesek motivációs reflexióiban határozottan megjelentek az állam és az önkormányzatok feladatrendszereinek nem megfelelő betöltéséből eredő hiányok kompenzálására tett erőfeszítések. Mivel hazánkban a kulturális szférában dolgozók meghatározó hányadát teszik ki az önkénteseknek, ezért ez, valamint a környezeti értékek fontossága is önálló motivációs faktor lett. A megkérdezett önkéntesek számára az értékeket kifejező motivációk voltak a legfontosabbak, vagyis az önkénteseket saját bevallásuk szerint főleg a másokon való segítés és egy társadalmi ügy vagy csoport melletti elköteleződés motiválja a leginkább, a vallás pedig a legkevésbé.

\section{KIEGÉSZÍTÉS A GYAKORLATI SZAKEMBEREK SZÁMÁRA}

Az alábbiakban olyan kutatási eredményeket ismertetünk, amelyek közvetlenebb gyakorlati hasznosításra is alkalmasak. Ez a fejezet kitér az önkéntesség szerepére a különböző életkorokban, a szerepeink és életfeladataink tükrében.

\section{Az önkéntesség motivációi a különböző életkorokban}

Mivel a legtöbb fenti önkéntes-motivációs kutatás felnőtt és idős személyeket vizsgált, fontosnak tartjuk kiemelni a fiatal korosztállyal végzett kutatások eredményeit is. Ennek oka, hogy már az előző Nemzeti Önkéntes Stratégia (2012-20) is célként fogalmazta meg, hogy minél több serdülőkorú és fiatal felnőtt személy kerüljön bevonásra. Ezen cél eléréséhez szükség van a korcsoportok motivációs hátterének megértésére is.

Egyértelműen látható, hogy a növekvő teljesítményelvárások miatt a nyugati társadalmakban serdülő- és ifjúkorban egyre gyakoribbá válik a szakmai önéletrajz fejlesztése céljából végzett önkéntes munka, ami felülírhatja a többi motivációs hajtóerőt (Handy et al. 2010). Ennek hátterében az áll, hogy a munkába álláshoz tapasztalatra van szükség, ami gyakran nehéz helyzetbe hozza a pályakezdőket. 
Egy ausztrál egyetemista mintán végzett kutatás (McCabe et al. 2007) szerint ugyanakkor a fent ismertetett Clary et al. (1999) által bemutatott motívumok közül a diákoknál a megértés és az érték dimenzió bizonyultak a legfontosabb önkéntes motivációnak. Sinisi et al. (1993) összefoglalója alapján azon középiskolás diákok, akik a Vöröskeresztnél és a United Waynél végeztek önkéntes munkát szolgálatuk keretében, jóval erősebb törődést mutattak más emberek problémái iránt, mint a nem önkéntes társaik. Ez igazolja a morális felelősségvállalás és értékrend, valamint az empátiás törődés önkéntességben betöltött szerepét. Ugyanerre jutott egy másik vizsgálat is (Moore et al 2014), ahol az érték és megértés motivációk magasabb, a karrier motiváció alacsonyabb szintje volt megfigyelhető.

Holdsworth (2010) szerint a fiatal korosztály önkéntes motivációi az altruisztikus és az énorientált késztetések keverékeként képzelhetők el: úgy végezhet szokásostól eltérő, kihívásteli, ugyanakkor szórakoztató tevékenységeket, hogy annak végzése összhangban áll identitásával, és kicsit kiléphet a komoly tanulási feladatok vagy munka nyomása alól. Ugyanakkor azt is fontos leszögeznünk, hogy a serdülőkori önkéntesség egyik fontos hajtóereje a hedonizmus („érezzük jól magunkat és éljünk át kellemes élményeket”) is (Rokach - Wanklyn 2009:19). Erre utal Serow (1991) vizsgálata is, aki az altruista motivációk mellett a jutalom elvárását is kimutatta az önkéntesség hátterében.

Érdemes egy pillantást vetnünk a több életkori szakaszt (fiatal, középkorú, idős) is bevonó kutatásokra: Omoto et al. (2000) azt találták, hogy a fiatalabb önkénteseket általában az interperszonális kapcsolatok motiválják, míg az idősebb önkénteseket inkább a közösség iránti kötelességtudat motiválja. Boling (2006) interjús és kérdőíves vizsgálatában ugyancsak azt találta, hogy az önkéntesek motivációi szignifikáns különbséget mutattak az életkor függvényében: Erikson $(1959,1968)$ elméleti alapvetéseinek gyakorlati alátámasztásaként a serdülők magasabb identitás-, az érett felnőttkorban levők magasabb generativitás-, az idősebbek pedig magasabb integritás motivációt mutattak az önkéntesség kapcsán, mint a többi korcsoport, egyedül az intimitás motiváció fiatal felnőttkori hipotézise nem igazolódott.

\section{Az önkéntes motivációk változása az idöperspektíva és a szerepek tükrében}

Az előzőekben ismertetett eredmények alapján feltehetjük azt a kérdést is, vajon milyen tényezők magyarázhatják az önkéntes motivációk megváltozását. Már Omoto et al. (2000) is 
rámutattak arra, hogy az önkéntes motivációk eredhetnek azokból az életfeladatokból, amelyekkel az egyén szembesül.

Az önkéntesség motivációs hátterének különböző életkori szakaszokkal, életeseményekkel való összefüggéseinek megértéséhez hasznos elmélet a szocioemocionális szelektivitás elmélete (Carstensen et al. 1999), mely szerint fiatalabb korban, amikor az előttünk álló időt korlátlannak látjuk, a karriercélok kiteljesítése, a tudás bővítése sokkal jellemzőbb motívum, mint később, amikor már korlátozottnak látjuk. Okun -Schultz (2003) vizsgálatában a társas kapcsolatok fenntartása (társas motiváció) mellett új faktorként megjelent a társas kapcsolatok kialakítására irányuló motiváció is. Eredményeik szerint az életkor előrehaladtával csökken a karrier és a megértés motivációk jelentősége, ugyanakkor a társas motiváció jelentősége nő, az érték, a növekedés és az énvédelem motivációk pedig nem mutatnak összefüggést az életkorral.

A szerzők további érdekes eredménye, hogy a 40-59 éves korcsoport számára kevésbé fontos az új kapcsolatok kialakítása az önkéntességen keresztül, mint a 70 évesnél idősebb önkéntesek számára. Ennek oka az is lehet a szerzők szerint, hogy ebben az időszakban rengeteget invesztálnak a családi és munkahelyi kapcsolati hálóikba. Külön kiemelendő, hogy úgy tûnik, hogy a nyugdíjba vonulás idején (60-69 év) az önkéntesség sokaknál segít újra felépíteni a társas kapcsolati hálót, tehát ekkor a társas motiváció jelentősége újra kiemelkedő. Dávila - Díaz-Morales (2009) szerint az életkor előrehaladtával az értékek kifejezésének, a társas kapcsolataink elmélyítésének, az érzelmi szükségletek önkéntesség általi betöltésének lehetősége válik fontosabb céllá, miközben a karrier, megértés és az új társas kapcsolatok szerzésének motivációs jelentősége fontosabb a fiatalabb önkéntesek számára.

Ugyanakkor azt is fontos kiemelnünk, hogy nem csak az életkor, hanem a különböző életkori szakaszok közötti átmenetek is hozzájárulhatnak a motivációs háttér megváltozásához (Baltes - Baltes 1990) azáltal, hogy specifikus fejlődési feladatokkal szembesítik az egyént. Az önkéntesség kapcsán kiemelkedő jelentőségű változás például a szülővé válás, ami a társas szerepek, felelősségi körök és a motivációk megváltozásával egyaránt járhat. Mivel a szülővé váló önkéntesek korlátozottabbnak élhetik meg az idejüket, mint a nem szülői státuszban levő önkéntesek, sokkal inkább szelektálnak a társas interakcióikban, és használják azokat érzelmileg jutalmazó tapasztalatok keresésére (Aydinli et al. 2015). 


\section{ÖSSZEGZÉS}

Az önkéntes megtartása érdekében hasznos az önkéntest foglalkoztató szervezeteknek és a vele közvetlen kapcsolatban álló koordinátoroknak az egyéni motivációs struktúrákat (explicit és implicit, másokra - énre orientált) azonosítani, és az így nyert információk mentén időről időre javítani az önkéntesség feltételeit.

A belső motiváció erősítése (a pszichológiai alapszükségletek kielégítése) mellett a hatékony külső ösztönzők alkalmazása (pl. elismerések, tréningek) is hozzájárulhat a motivált munkavégzés fennmaradásához. A motivációs háttér azonosítása és ezen motívumok kiteljesítése kimutathatóan növeli az önkéntes elégedettségét és a tevékenység folytatására irányuló szándékát is (Omoto - Snyder 1995). Snyder et al. (2000) szisztematikus elemzésük során például azt találták, hogyha egy önkéntest elsősorban társas szükségletek motiválnak akkor, ha ezeket a szükségleteket segíti a szervezet kielégíteni, az önkéntesek magasabb elégedettségről és boldogságról számolnak be, mintha karrierrel összefüggő vagy értékkifejező jutalmakban részesültek volna.

Fontos látnunk, hogy az életkori szakasznak, az aktuális életeseményeinknek, az önkéntesség során megélt tapasztalatoknak, a közösségnek, de az önkéntest fogadó szervezet által nyújtott szakmai lehetőségeknek egyaránt szerepe van a motivációs jellemzők alakulásában.

\section{IRODALOM}

Allison, L. D. - Okun, M. A. - Dutridge, K. (2002): Assessing volunteer motives: A comparison of an open-ended probe and Likert rating scales. Journal of Community \& Applied Social Psychology, 12, pp. 243-255. doi:10.1002/casp.677

Amabile, T. M. (1993): Motivational synergy: Toward new conceptualizations of intrinsic and extrinsic motivation in the workplace. Human Resource Management Review, 3(3) pp. 185-201.

Aydinli, A. - Bender, M. - Chasiotis, A. - Cemalcilar, Z. - van de Vijver, F. J. (2014): When does selfreported prosocial motivation predict helping? The moderating role of implicit prosocial motivation. Motivation and Emotion, 38(5) pp. 645-658.

Aydinli, A. - Bender, M. - Chasiotis, A. - van de Vijver, F. J. - Cemalcilar, Z. (2015): Implicit and explicit prosocial motivation as antecedents of volunteering: The moderating role of parenthood. Personality and Individual Differences, 74. pp. 127-132.

Aydinli, A. - Bender, M. - Chasiotis, A. - van de Vijver, F. J. - Cemalcilar, Z. - Chong, A. - Yue, X. (2016): Across-cultural study of explicit and implicit motivation for long-term volunteering. Nonprofit and Voluntary Sector Quarterly, 45(2) pp. 375-396. 
Baltes, P. B., - Baltes, M. M. (1990). Psychological perspectives on successful aging: The model of selective optimization with compensation. In. Baltes, P.B. - Baltes M. M. (eds.): Successful aging: Perspectives from the behavioral sciences Cambridge University Press pp. 1-34 DOI: https://doi.org/10.1017/СВ09780511665684.003

Bartal Anna Mária (2010): Mit mutat a kaleidoszkóp? Az Önkéntes Motivációs Leltár (Volunteer Motivation Inventory) adaptálása, fejlesztése és kipróbálása a magyar önkéntesek körében. Civil Szemle, 7(1) pp. 5-35.

Bartal Anna Mária - Kmetty Zoltán (2011): A magyar önkéntesek motivációi - a Magyar Önkéntes Motivációs kérdőív sztenderdizálásának eredményei alapján. Civil Szemle, 8(4) pp. 7-30.

Bidee, J. - Vantilborgh, T. - Pepermans, R. - Huybrechts, G. - Willems, J. - Jegers, M. - Hofmans, J. (2013): Autonomous motivation stimulates volunteers' work effort: A self-determination theory approach to volunteerism. Voluntas: International Journal of Voluntary and Nonprofit Organizations, 24(1) pp. 32-47.

Boling, A. L. (2006). Volunteer motivations across the lifespan. The Claremont Graduate University.

Brunell, A. B. - Tumblin, L. - Buelow, M. T. (2014). Narcissism and the motivation to engage in volunteerism. Current Psychology, 33(3) pp. 365-376.

Carstensen, L. L. - Isaacowitz, D. M. - Charles, S. T. (1999). Taking time seriously: a theory of socioemotional selectivity. American Psychologist, 54(3) p. 165.

Chacón, F. - Gutiérrez, G. - Sauto, V. - Vecina, M. L. - Pérez, A. (2017): Volunteer Functions Inventory: A systematic review. Psicothema, 29. pp. 306-316.

Chasiotis, A. - Hofer, J., \& Campos, D. (2006): When does liking children lead to parenthood? Younger siblings, implicit prosocial power motivation, and explicit love for children predict parenthood across cultures. Journal of Cultural and Evolutionary Psychology, 4(2) pp.95-123.

Clary, E. - Snyder, M. - Ridge, R. D. - Copeland, J. - Stukas, A. A. - Haugen, J., - Miene, P. (1998): Understanding and assessing the motivations of volunteers: A functional approach. Journal of Personality and Social Psychology, 74. pp. 1516-1530. doi:10.1037/0022-3514.74.6.1516

Dávila, M. C- Díaz-Morales, J. F. (2009): Age and motives for volunteering: Further evidence. Europe's Journal of Psychology, 5(2) pp. 82-95.

Davis, M. H. - Hall, J. A. - Meyer, M. (2003): The first year: Influences on the satisfaction, involvement, and persistence of new community volunteers. Personality and Social Psychology Bulletin, 29(2) pp. 248-260.

Deci, E. L. - Ryan, R. M. (1985): Intrinsic motivation and self-determination in human behavior. New York: Plenum.

Deci, E. L., - Ryan, R. M. (2000): The "what" and "why" of goal pursuits: Human needs and selfdetermination of behavior. Psychological Inquiry, 11. pp. 227-268.

Deci, E. L., - Ryan, R. M. (2002): Handbook of Self-Determination Research. Rochester, NY: University of Rochester Press.

Deci, E. L., - Ryan, R. M. (2008): Self-determination theory: A macrotheory of human motivation, development, and health. Canadian Psychology, 49(3) pp. 182-185.

Dorner L. (2020): Az önkéntesség lélektani vonatkozásainak empirikus vizsgálatai. Debreceni Egyetem Humán Tudományok Doktori Iskola.

Erikson, E. H. (1959): Identity and the life cycle: Selected papers.

Erikson, E. H. (1968). Identity: Youth and crisis (No. 7). WW Norton \& company. 
Esmond, J., - Dunlop, P. (2004): Developing the volunteer motivation inventory to assess the underlying motivational drives of volunteers in Western Australia, Lotterywest. http://www.clanwa.com.au/resources/VolMotExecSummary.

Finkelstein, M. A. (2009): Intrinsic vs. extrinsic motivational orientations and the volunteer process. Personality and Individual Differences, 46, 653-658.

Fox, J. - Machtmes, K. - Tassin, M.- Hebert, L. (2010): An analysis of volunteer motivations among youth participating in service-learning projects. Information for Action, 2(1) pp. 1-19.

Gagné, M. (2003). The role of autonomy support and autonomy orientation in prosocial behavior engagement. Motivation and Emotion, 27(3) pp. 199-223.

Gibson, T. (2008). Religion and civic engagement among America's youth. The Social Science Journal, 45(3) pp. 504-514.

Grube, J. A. - Piliavin, J. A. (2000): Role identity, organizational experiences, and volunteer performance. Personality and Social Psychology Bulletin, 26(9) pp. 1108-1119.

Güntert, S. T. - Strubel, I. T. - Kals, E. - Wehner, T. (2016): The quality of volunteers' motives: Integrating the functional approach and self-determination theory. The Journal of Social Psychology, 156(3) pp. 310-327.

Handy, F. - Brodeur, N. - Cnaan, R. A. (2006): Summer on the island: episodic volunteering. Voluntary Action, 7(3) pp. 31-46.

Hochstetler, J. J. (2014). Revising the Volunteer Functions Inventory: An exploratory study of additional functions. Northcentral University.

Konrath, S. - Fuhrel-Forbis, A. - Lou, A. - Brown, S. (2012): Motives for volunteering are associated with mortality risk in older adults. Health Psychology, 31(1) p. 87.

Konrath, S., Ho, M. H., Zarins, S. (2016): The strategic helper: Narcissism and prosocial motives and behaviors. Current Psychology, 35(2) pp. 182-194.

Martos Tamás (2016): Motiváció, értékek és társas kapcsolatok: az öndetermináció elméletének alapjai. In. Baritz, S.L. - Dabóczi G. (szerk.) Emberközpontú gazdaság: A Keresztény Társadalmi Elvek a Gazdaságban (KETEG) képzés szakkönyve Budapest: KETEG Oikonomia Kutató Intézet Alapítvány, pp. 242-255.

Moore, E. - Warta, S. - Erichsen, K. (2014): College students' volunteering: factors related to current volunteering, volunteer settings, and motives for volunteering. College Student Journal, 48(3) pp. 386396.

McClelland, D. C. - Pilon, D. A. (1983): Sources of adult motives in patterns of parent behavior in early childhood. Journal of Personality and Social Psychology, 44(3) p. 564.

McClelland, D. C. - Koestner, R. - Weinberger, J. (1989): How do self-attributed and implicit motives differ? Psychological Review, 96(4) pp. 690.

Okun, M. A. - Schultz, A. (2003): Age and motives for volunteering: Testing hypotheses derived from socioemotional selectivity theory. Psychology and Aging, 18(2) p. 231.

Omoto, A. M. - Snyder, M. (1995): Sustained helping without obligation: motivation, longevity of service, and perceived attitude change among AIDS volunteers. Journal of Personality and Social Psychology, 68(4) p. 671.

Omoto, A. M. - Snyder, M. - Martino, S. C. (2000): Volunteerism and the life course: Investigating agerelated agendas for action. Basic and Applied Social Psychology, 22(3) pp. 181-197. 
Perugini, M. - Conner, M. - O'Gorman, R. (2011): Automatic activation of individual differences: A test of the gatekeeper model in the domain of spontaneous helping. European Journal of Personality, 25(6) pp. 465-476.

Pólya, B. - Martos, T. (2012): Miért jó önkéntes munkát vállalni? Az önkéntesség és az élettel való elégedettség kapcsolata öndetermináció-elméleti megközelítésben. Mentálhigiéné és Pszichoszomatika, 13(3) pp. 255-271.

Rokach, A. - Wanklyn, S. (2009): Motivation to volunteer: Helping empower sick children. Psychology and Education: An Interdisciplinary Journal, 46(1) pp. 7-25.

Ryan, R. M. - Deci, E. L. (2000a): Intrinsic and extrinsic motivations: Classic definitions and new directions. Contemporary Educational Psychology, 25(1) pp. 54-67.

Ryan, R. M. - Deci, E. L. (2000b): Self-determination theory and the facilitation of intrinsic motivation, social development, and well-being. American Psychologist, 55(1) p. 68.

Ryan, R. M. - Deci, E. L. (2017): Self-Determination Theory. New York, NY: The Guilford Press

Ryan, R. M. - La Guardia, J. G. (2000): What is being optimized? Self-determination theory and basic psychological needs. In. Qualls, S.H. - Abeles, N. (eds.): Psychology and the aging revolution: How we adapt to longer life. pp. 145-172. Washington, DC: American Psychological Association.

Schultheiss, O. C. (2008): Implicit motives. In. John, O.P. - Robins, R.W. - Pervin, L.A. (eds). Handbook of personality: Theory and research. New York, NY: Guilford Press. pp. 603-633

Serow, R. C. (1991): Students and voluntarism: looking into the motives of community service participants. American Educational Research Journal, 28(3) pp. 543-556.

Shantz, A. - Saksida, T. - Alfes, K. (2014): Dedicating time to volunteering: Values, engagement, and commitment to beneficiaries. Applied Psychology, 63(4) pp. 671-697.

Sinisi, C. - Barnett, M. A. - Sprague, S. S. (1993): Factors affecting the decision to volunteer. Poster presented at the biennial meeting of the Society for Research In. Child Development, New Orleans, LA, March pp. 25-28.

Snyder, M. - Clary, E. - Stukas, A. (2000): The functional approach to volunteerism. In G. Maio \& J. Olson (eds.), Why we evaluate: Functions of attitudes. Mahwah, NJ: Erlbaum. pp. 365-393.

Snyder, M. - Omoto, A. M. (2009): Who gets involved and why? The psychology of volunteerism. Youth empowerment and volunteerism: Principles, Policies and Practices, pp. 3-26.

Vecina, M. L. - Marzana, D. (2019): Motivations for volunteering: Do motivation questionnaires measure what actually drives volunteers?. TPM: Testing, Psychometrics, Methodology in Applied Psychology, 26(4) pp. 573-587.

Weinstein, N. - Ryan, R. M. (2010): When helping helps: Autonomous motivation for prosocial behavior and its influence on well-being for the helper and recipient. Journal of Personality and Social Psychology, 98(2) pp. 222.

Widjaja, E. (2010): Motivation behind volunteerism. CMC senior theses. Paper 4. 